\title{
Aspiration failure
}

A poverty trap for indigenous children in Peru?

Laure Pasquier-Doumer and Fiorella Risso Brandon 



\title{
Aspiration failure A poverty trap for indigenous children in Peru?
}

\author{
Laure Pasquier-Doumer and Fiorella Risso Brandon
}

This paper was presented at a conference on Inequalities in Children's Outcomes in Developing Countries hosted by Young Lives at St Anne's College, Oxford on 8-9 July 2013.

http://www.younglives.org.uk/news/news/children-inequalities-younglives-conference-2013

The data used come from Young Lives, a longitudinal study of childhood poverty that is tracking the lives of 12,000 children in Ethiopia, India (in Andhra Pradesh), Peru and Vietnam over a 15-year period. www.younglives.org.uk

Young Lives is funded from 2001 to 2017 by UK aid from the Department of International Development and co-funded by the Netherlands Ministry of Foreign Affairs from 2010 to 2014.

The views expressed are those of the author(s). They are not necessarily those of the Young Lives project, the University of Oxford, DFID or other funders. 


\title{
Aspiration failure: A poverty trap for indigenous children in Peru?
}

\author{
Laure Pasquier-Doumer and Fiorella Risso Brandon
}

First published by Young Lives in December 2013

(C) Young Lives 2013

ISBN: 978-1-909403-29-1

A catalogue record for this publication is available from the British Library. All rights reserved. Reproduction, copy, transmission, or translation of any part of this publication may be made only under the following conditions:

- with the prior permission of the publisher; or

- with a licence from the Copyright Licensing Agency Ltd., 90 Tottenham Court Road, London W1P 9HE, UK, or from another national licensing agency; or

- under the terms set out below.

This publication is copyright, but may be reproduced by any method without fee for teaching or non-profit purposes, but not for resale. Formal permission is required for all such uses, but normally will be granted immediately. For copying in any other circumstances, or for re-use in other publications, or for translation or adaptation, prior written permission must be obtained from the publisher and a fee may be payable.

Printed on FSC-certified paper from traceable and sustainable sources.

Funded by

Young Lives, Oxford Department of International Development (ODID), University of Oxford, Queen Elizabeth House, 3 Mansfield Road, Oxford OX1 3TB, UK

Tel: +44 (0)1865 281751 •E-mail: younglives@younglives.org.uk 


\section{Contents}

$\begin{array}{ll}\text { Abstract } & 2\end{array}$

$\begin{array}{ll}\text { Acknowledgements } & 2\end{array}$

The Authors 2

1. Introduction 3

2. Data, concepts and definitions $\quad 8$

$\begin{array}{ll}\text { The data } & 8\end{array}$

How do we define indigenous people? 9

How do we define aspirations of the children? 10

How do we classify aspirations? 11

How do we measure aspiration gap? 12

3. Which occupations do Peruvian children aspire to? 13

4. How are aspirations shaped? 15

$\begin{array}{ll}\text { Empirical strategy } & 15\end{array}$

$\begin{array}{ll}\text { Results } & 17\end{array}$

5. The effect of the aspiration gap on educational attainment 19

6. Conclusion 22

$\begin{array}{ll}\text { References } & 24\end{array}$

$\begin{array}{ll}\text { Appendix } & 28\end{array}$ 


\begin{abstract}
This paper aims to contribute to understand the mechanisms underlying the complex exclusion process of indigenous people in Peru, by analysing the role played by aspirations in the investment in education of indigenous children. To address these issues, the paper relies on a very rich data set, the Young Lives data, and use an original instrument that allow to cast light on the causal relation between aspiration and educational outcomes. We find that aspiration failure is a channel of inequality persistence between indigenous and nonindigenous people, but that aspiration failure do not takes the form of a lack of aspiration. Indigenous children do not have internalized racial schemas about occupation or about their opportunities. However, the gap between their aspiration and their current socio-economic status is too large, in so far as it has a disincentive effect on forward-looking behaviour.
\end{abstract}

\title{
Acknowledgements
}

The authors thank Javier Herrera and Javier Escobal for fruitful suggestions and stimulating discussions, and for their help in the access to the data. We also thank participants in the Young Lives Conference "Inequalities in Children's Outcomes in Developing Countries" (Oxford, July 2013) for their comments. This paper has received funding from the NOPOOR project (www.nopoor.eu) under the FP7 of the European Commission.

\section{The Authors}

Laure Pasquier-Doumer holds a $\mathrm{PhD}$ in development economics and is researcher at DIAL, a research unit of the French Research Institute for Development (IRD) and the University of Paris Dauphine. Her research focuses on inequality of opportunity in the labour market and in education.

Fiorella Risso Brandon is a $\mathrm{PhD}$ candidate in Economics at University Paris Dauphine. Her areas of expertise include poverty, inequality of opportunity, and discrimination in Peru. 


\section{Introduction}

Since the last decade, Peru has experienced dramatic poverty alleviation, in both rural and urban areas and for various dimensions of poverty. Although incidence of poverty among indigenous people also decreased, it has not reduced in relative terms. The gap between indigenous and non-indigenous people remains as high as it was 10 years ago. Hence, the monetary poverty rate among indigenous people is 1.6 times higher than among nonindigenous people in 2010 , reaching $42.5 \%$ compared to $25.8 \%$ for non-indigenous people, while it was 1.3 times higher in 2004 (INEI 2011).

Intergenerational poverty trap for indigenous people is widely acknowledged and documented in Peru (Escobal and Ponce 2007; Cueto et al. 2009; Trivelli 2005; Figueroa 2006; Barrón 2005; Ñopo, Saavedra and Torero 2004; Mac Isaac 1994). These studies lead to the conclusion that exclusion, understood as discrimination in access, is the main driver of inequality. In addition, exclusion mechanisms operate mostly when individuals are acquiring skills. While discrimination in the labour market seems to be low, coming from an indigenous family is an important predictor of low educational outcomes, in terms of repetition, dropout or attainment (Cueto 2007, Escobal and Ponce 2007). Barrón (2008) estimates that partial reductions of exclusion in the access to education would reduce inequality as much as the complete elimination of discrimination. Pasquier-Doumer (2002) stress the structural dimension of the inequality in access to education between indigenous and non-indigenous people, as the gap in access to secondary or high education between the two groups has widened throughout the second half of the twentieth century.

However, very little is known on how the exclusion mechanisms of indigenous people operate. Cueto et al. (2009) show that poverty status, geographical localization, or other characteristics of indigenous households only explain a marginal portion of the low educational achievement of indigenous children, while educational process and peer effects play a crucial role. But many unanswered questions remain on how the educational process and the clustering effect lead to the exclusion of indigenous children.

This paper aims to contribute to understand the mechanisms underlying the complex exclusion process of indigenous people in Peru, by analysing the role played by aspirations. In a common definition, aspiration is a desire or ambition to achieve something. This concept suggests that some effort would be exerted to realize the desired aim or target. Following 
Bernard and Tafesse (2012), "aspirations combine or summarize the preferences maintained, the beliefs held, and possibly the constraints acknowledged by an individual about aspects of the future" (p.3).

Studying aspiration as a channel of intergenerational transmission of inequalities results of a long tradition in psychological and sociological literature. ${ }^{1}$ In particular, a strand of research focuses on the shaping of aspirations for ethnic minorities and analyses what is the effect of aspiration of ethnic minorities on their outcomes (Kuvlesky and Patella 1971, Cosby and Picou 1973, Kao and Tienda 1998; Qian and Blair 1999; Goldenberg et al. 2001; St-Hilaire 2002; Bigler, Averhart and Liben 2003, Glick and White 2004, Zhang et al. 2011). Most of these studies conclude that ethnic belonging is a strong predictor of aspirations, which in turn influence outcomes. Results are more controversial when socio-economic status is properly taken into account. However, all of these studies are conducted in the USA and related to Black-, Hispanic- or Asian-American minorities.

More recently, a growing economic literature addresses the relationship between poverty, inequality and aspirations. This strand of research, inspired by behavioural economics, aims to overcome the neo-classical analysis of poverty in which decision-making is only shaped by structural constraints that poverty imposes. As stressed by Duflo (2006) "what is needed is a theory of how poverty influences decision-making, not only by affecting the constraints, but by changing the decision-making process itself' (p.378). Recent theoretical developments and some evidences support the idea that aspirations is of principal concern for poverty reduction and equality of opportunity.

While some authors as Piketty (1998) introduced prospect for future social status in the formalization of the dynamic of inequalities, the concept of aspiration as such is introduced for the first time in the economic literature by Ray (2006). Inspired by the work of the anthropologist Appadurai (2004) on 'the capacity to aspire', Ray defends the idea that poverty and the failure of aspirations are reciprocally linked in a self-sustaining trap. For these authors, aspirations are socially determined. Ray defines the concept of 'aspirations window' that one forms from lives or achievement of 'similar' or 'attainable' individuals. The effect of aspiration on behaviour is then channelling by the 'aspiration gap', defined as the difference

\footnotetext{
${ }^{1}$ In line with Marxist sociology, Reissman (1953) intended in a pioneer work to formalize the link between aspiration and social class. In the 1970's, various social psychology studies are conducted to understand how aspiration affect child development and attainment.
} 
between the standard of living that is aspired to and the standard of living that one already have. In case of very small or very wide aspiration gap, individuals have little incentive to raise standards, because the distance to fill the gap is too small or too large. Ray adds that for a polarized society such as that of Peru, the aspiration gap of poor people will be too large if the poor do aspire to be like the rich or too small if they do not include the rich in their aspiration window.

Along similar line, Page (2005) offers a formalization of the causal link between aspirations and educational behaviour using the notion of reference point from prospect theory. In a model of human capital accumulation, Mookherjee, Napel and Ray (2010) emphasize aspirations formation as a key factor of accumulation incentives. By introducing local complementarities in the aspirations formation -social interactions with skilled neighbours raise parental aspirations for their children-, they are able to explain inequality persistence without hypothesis of capital-market imperfection or spatial mobility of agents. As argued by the authors, social networks based on ethnicity can play a role analogous to those of one's physical neighbours in their model.

Beside theoretical developments, recent evidences related to developing countries suggest that integrating aspiration formation in the understanding of poverty trap and inequalities persistence is of principal concern. Bernard, Dercon and Tafesse (2011) observe a small aspiration gap in rural Ethiopia, which goes hand in hand with low self-efficacy. Aspiration gap is measured as one's belief that she could become as successful as her role model within five years. In addition, aspiration failure and low self-efficacy correlate with underinvestment as they lower demand for long-term credit and the productive use of this credit. Relying on qualitative and quantitative data, Camfield et al. (2012) find evidence of an adaptation process in Thailand, which leads the poor to stop aspiring to what they cannot achieve. As argued by the authors, this aspiration failure could explain why objective poverty does not affect people's satisfaction with their lives in Thailand. With qualitative interview in Egypt, Ibrahim (2011) highlights intergenerational transmission of aspirations' failure for poor people, which could be a channel of inequality persistence. In Peru, Dercon and Krishnan (2009) explores the relationship between material poverty and educational aspiration of children using the Young Lives data. They find a strong and positive correlation between material circumstances and educational aspirations. 
However, these studies fail to address two main questions. First, what are the mechanisms by which aspirations are shaped in developing countries? Are aspirations culturally or socially determined as argued by Ray (2006), Appadurai (2004), or as suggested by Sen (2004), who defends the idea that culture plays a major role in value formation? Or are aspiration shaped by external constraints through an individual adaptation process? In other words, do aspirations differences between two groups result from cultural differences between the two groups or do they only reflect different level of constraint? The first hypothesis will be called the 'internal channel hypothesis' later on, and the second one the 'external channel hypothesis'. To clearly distinguish these two channels, let's quote Rao and Walton (2004): "an economist may find it helpful to think of this internalization of the perceived possibility of success or failure as a constraining preference that interacts with exogenous constraints to affect human action (...). The incest taboo, for example, is a feature of most human societies. Most people would not consider breaking it, not just because of fear of social sanctions, but simply because the taboo is so deeply ingrained within their psyches. Thus the taboo is simultaneously an inherent preference against incest and a social constraint." (p.15).

Getting back to our main concern, how ethnic group can shape aspirations? Following the 'internal channel hypothesis', being indigenous may lead to an aspirations failure if indigenous people have internalized the discriminatory values of the "criolla'" elite, and then their objective chances of attaining a "high" socio-economic status. This idea is supported by a recent literature that highlights the link between current inequality and the colonial past of Latin American countries through a 'path dependence' process (Acemoglu, Johnson and Robinson 2002, Mahoney 2003, Engerman and Sokoloff 2005). Internalization of discriminatory value is also observed by Hoff and Pandey (2006) in India. Relying on an experiment, they show that making caste salient hurt low caste performance. In Peru, the symbolic prestige of being 'white' is widely acknowledge as a legacy of the colonial era (1514-1821). Some evidences show that it generates racism and socio-racial discrimination, and that indigenous people have internalized these discriminatory values (Portocarerro 1993, Henríquez 1995, Ames 2012). Thus, this process defined by Bourdieu (1997) as "symbolic violence" may limit the aspiration window of indigenous people and perpetuate inequalities.

On the other hand, being indigenous is also associated with other characteristics, such as being poor or living in a rural environment. These characteristics or 'external constraints' may

\footnotetext{
2 'Criolla' or 'criollo' refers to people who is Spanish descent but is born in Spanish-America.
} 
be the main determinant of an aspiration failure, as they limit access to information or opportunity to invest in the future. As instance, following the 'external constraints' hypothesis, the children may not aspire to be a doctor because they know that their parents would not have the funds to pay their studies. With the 'internal channel hypothesis', they will not aspire to be a doctor because they think that a doctor has to be 'white' or that they are not smart enough to succeed at medical school. In the line of the 'external channel hypothesis', some authors highlight major transformations of the Peruvian which allowed some indigenous people to relax their constraints and to consequently benefit from economic success (De Soto 1986, Golte and Adams 1987, Adams and Valdivia 1991, Hubert 1997, Mendoza 1997). These transformations are the integration of indigenous people to the democratic process ${ }^{3}$, the huge development of education, and the massive migration to urban areas.

The policy implications of the 'internal channel' and 'external channel' hypothesis are dramatically different. In the latter case, 'leveling the playing field' for indigenous people -to quote the metaphor that Roemer (1998) used to define equality of opportunity- would be enough to reduce the persistence of inequalities. In other words, proving equal access to human and physical capital to indigenous people, by alleviating the exogenous constraints they face, would be efficient. In the former case however, these policies will not be sufficient to break the vicious circle of poverty for indigenous people.

Second, another gap in the existing literature is that the causal effect of aspiration on forwardlooking behaviour is not well established. Most of the studies linking aspiration and poverty rely on cross-sectional data, and consequently are not able to address the endogeneity issue due to reverse causality and unobserved variables. Indeed, unobserved characteristics may jointly determine aspiration and forward-looking behaviour, and aspiration may be adjusted to outcomes of looking-forward behaviour. Studying the causal impact of aspiration on educational choices, Page, Levy Garboua and Montmarquette (2007) overcome the endogeneity problem by using an experiment. However, their experiment may seem very far from the purpose they aim to analyze. It consists of asking individuals to solve a given number of anagrams. Individuals are reward if they reach different levels of difficulty. Indeed, in this experiment, time and money investments to perform the task are proxy of educational choices and the expected gains of the game relative to an initial sum reflect the aspiration gap. In addition, their experiment is conducted in France. The link between aspiration and

\footnotetext{
${ }^{3}$ The 1979 Constitution provided for universal suffrage and allowed illiterate people to vote, knowing that the bulk of indigenous people was illiterate.
} 
behaviour may be different in Peru than in France, because of a high constraint level for the poor due to market imperfection, and because the social stratification is partly shaped by the colonial past of Peru.

Based on these perspectives, this paper investigates first whether aspirations of indigenous people differ from the ones of non-indigenous people in Peru, and if so, through which mechanisms. It seeks to identify the respective relevance of the 'internal channel hypothesis' and the 'external channel hypothesis' in the Peruvian context, using a dynamic approach of aspiration formation. Then, the paper aims to cast light on the causal relation between aspiration and educational success. It encompasses the question whether aspiration failure leads to underinvestment in education. To tackle these issues, the paper relies on a very rich data set, the Young Lives data.

Section 2 presents the data, and defines the concepts used in the paper. Section 3 describes the aspirations and the aspiration gap of the children, and their dynamic. Section 4 examines the determinants of aspirations and the role of ethnic group. Section 5 analyses the causal link between aspiration failure and educational outcomes. Section 6 summarizes and concludes.

\section{Data, concepts and definitions}

\section{The data}

We used survey data of the Young Lives project. Young Lives (YL) is a longitudinal study of childhood poverty for understanding its causes and consequences, and in order to influence the formulation of public policies. It is led by a team in the Department of International Development at the University of Oxford. In association with other partners, the data are collected in four countries: Ethiopia, India (Andhra Pradesh), Peru ${ }^{4}$ and Vietnam. It follows over 15 years two cohorts of children, the Younger cohort and the Older cohort, born in 200102 and 1994-95 respectively. They were first surveyed in 2002, and then every four years. So far, the data are available for three rounds: 2002 (R1), 2006 (R2) and 2009 (R3).

\footnotetext{
${ }^{4}$ In Peru, the project is implemented by three institutions: Instituto de Investigacion Nutricional (INN), Grupo de Analisis para el desarrollo (GRADE) and Save the Children UK.
} 
The YL data are unique among developing countries. Indeed, through interviews with large cohorts of children and their caregiver, a wealth of information are collected in a dynamic way, not only about the material and social circumstances of the children, but also about perspectives on their lives and aspirations for the future, as on the environmental and social realities of their communities. In particular, for the older cohort, children are interviewed on their educational and occupational aspiration at each round.

In Peru, the two cohorts of children were selected using a multi-stage, cluster-stratified and random sampling, and with a pro-poor bias, ensuring that the sample represents $95 \%$ of the population excluding children in the richest 5\%. YL households are found to be very similar to the average household in Peru, although they may have better access to some services (Escobal and Flores 2008). In this paper, we use the post-stratification proposed by Escobal and Flores (2008), to minimize the potential bias.

In this paper, we focus on the older cohort, surveyed at 8, 12 and 15 years old. This cohort includes 714 children in 2002, 685 children in 2006, and 678 children in 2009. The low attrition rates between the three rounds (5\% between 2002 and 2009) are a key factor of quality of these data as well.

\section{How do we define indigenous people?}

Ethnic group is a complex and controversial concept. It is multidimensional, as an ethnic group is a group of people whose members share some common characteristics which could be both cultural, as language or religion, and geographical as a place of origin or a territory. It is a moving concept in time and space also. Therefore, it is problematic to define ethnic belonging with only one criterion. In Peru, the term indigenous commonly refers to the people belonging to Andean ethnic groups Quechua and Aymara, and the Amazonian ethnic groups. However, the huge transformations experienced by the Peruvian society, as mestizaje and migration, have made this concept quite fuzzy, as stressed by many authors.

In the YL data, ethnic group can be defined by self-identification or by ascription. Selfidentification measure does not reduce the definition of ethnic group to one dimension. But it is widely acknowledged that self-identification underestimates the size of indigenous population in the Peruvian context (Nopo, Saavedra, and Torero 2004), where discriminatory 
values against indigenous people are internalized, as already stressed. However, in the YL data, it has been asked to the caregiver to define her ethnic group and the one of her child, by choosing one answer from the following list: "White, Mestizo (include Andean indian), Native of Amazon, Negro, Asiatic, other". Following this definition, 97\% of the population is indigenous. The unclear boundaries of the Mestizo concept and maybe the willing to avoid this sensitive question may explain that the bulk of interviewed people defines herself as mestizo. In any case, this variable seems not reliable to define indigenous people here.

The language is the criterion most widely used in the empirical literature for identifying indigenous people. Beyond the fact that it is easy to define and measure, language is a central element of a culture and process of social cohesion. According to the United Nations, language, and especially the mother tongue, is a key variable for identifying ethnic groups. More than 40 indigenous languages are spoken in Peru, most in the Amazon and with a relatively small number of speakers. Quechua is the most frequent indigenous language and is spoken widely in the Andes. Aymara is the second most frequent indigenous language, spoken mostly in the Southern part of the Peruvian Andes. However, the language criterion not only reduces ethnic belonging to one dimension, it also underestimates the indigenous population as shown by Nopo, Saavedra, and Torero (2004), mostly because of migration to urban areas that reinforce learning Spanish. To mitigate these limitations, we widen the definition to the grandparents tongue. Children are defined as indigenous if the first language of one of their parents (mother, father or caregiver) learned as a child is Quechua, Aymara or a language of the Amazon. Following this definition, $48 \%$ of the children are indigenous in our sample.

\section{How do we define aspirations of the children?}

The concept of aspirations is multidimensional. As recalled by Bernard and Tafesse (2012), aspirations span multiple and potentially interrelated dimensions. Individuals may have wealth or income aspirations, educational aspirations, social status aspirations, or aspirations about others such as their children. However, the vast majority of studies that address the issue of aspirations restrict the definition of aspirations to one dimension. The reason for this is mainly the difficulty to aggregate various dimensions of aspirations into a single indicator. The dimensions most frequently tackled are income aspirations and educational aspirations. Both have the advantage that they can be measured by an ordered indicator. 
In this paper, we prefer to focus on occupational aspirations of the children for two main reasons. First, it is widely acknowledged that the division of labour is a key factor of social inequality. Occupation reflects very closely the social status, which integrates the notion of wealth, but also of power and prestige in its Weberian conception. Occupation is therefore a more multi-dimensional concept than income or education. The second reason for studying occupational aspirations is that educational aspirations are very high in the context of Peru, whatever the characteristics of the families. This phenomenon is well known in Peru as the "education myth". Ansión et al. (1998) highlight that in Lima, 95\% of parents want that their children attain a grade higher than secondary. In the YL survey, around $90 \%$ of the 12 aged children want to reach a post-secondary level and $77 \%$ want to complete university. Because of this lack of variance, it seems not appropriate to use educational aspirations in the Peruvian context to understand the determinants of aspirations.

In the first two rounds of the YL's survey, children have been asked what they want to be when they grow up. In the R1, children had to choose an occupation from a list of seven modalities but could also add another one. Because a quarter of children listed an occupation out of the list, a total of 40 different occupations have been mentioned. In the R2, the list was larger, including 32 modalities. At the end of the day, 43 occupations have been proposed in the R2. Unfortunately, the wording of the question has been changed in the R3, to capture children expectation rather than children aspiration. For this reason, the R3 is not used in this paper to measure aspiration. It will be only used to measure educational outcomes.

\section{How do we classify aspirations?}

The difficulty of conducting quantitative analysis based on occupation is to classify them in an ordered way. To face this difficulty, we use a measure of socio-economic status that is commonly used in sociology. Indeed, recognizing that occupation is the main dimension of social stratification, stratification researchers have developed ways to derive status measures from information on occupations. We adopt the same approach as Ganzeboom and Treiman (1996) to calculate the International Socio-Economic Index of occupational status. In this approach, scores are created by computing a weighted sum of socioeconomic characteristics related to each occupation, usually education and income. It has been widely acknowledged 
by sociologists that this approach allows capturing the basic parameters of the process of stratification.

First, occupational aspirations have been recoded using the 3-digit International Standard Classification of Occupation 2008 (ISCO-08). In a second step, we assign a score to each occupation, which is a linear combination of the average level of education required by the occupation and the average income it generates. To compute this score, we use the Encuesta Nacional de Hogares (ENAHO), a representative survey of the Peruvian population carried out in 2006, with around 62.000 individuals. The average level of income and the average years of education of one occupation have been standardized and added up with the same weight, as the various procedures used in the literature to derive the weights conclude all to more or less the same weight for education and income (Ganzeboom and Treiman 1996).

The scores of the occupation that children aspire to are used as a metric measure of the social status the children aspire to, which is ordered according to education and income criteria. Let's denote it as $S^{A}$. As a robustness check and to take into account non-linear effect, we also use an ordered-categorical measure of aspiration, denoted $S G^{A}$, which is calculated by aggregating occupations into four groups, defined as the quartiles of the score from all the occupations listed by the children in R1, and R2. $S G^{A}$ takes the values 1 to 4 . Table 1 presents the average income, the level of education and the standardized score for each group and Table 2 gives the composition of each group in terms of occupations. The most representative occupation for the low aspirations group $\left(S G^{A}=1\right)$ is "agricultural worker", while it is "driver" or "mechanic" for the intermediate aspirations group $\left(S G^{A}=2\right)$, "teacher" for the high aspirations group $\left(S G^{A}=3\right)$ and "medical doctor" or "engineer" for the very high aspirations group $\left(S G^{A}=4\right)$.

[Tables 1 and 2 here]

\section{How do we measure aspiration gap?}

Following Ray (2006) aspiration gap is defined as the difference between the social status that is aspired to and the social status that one already have. As the social status that the children aspire to is measured by the score of occupational aspirations $S^{A}$, we would like to use the occupation of the parents to measure the actual social status of the children in a comparable 
way. Unfortunately, only sectors of activity of the parents are collected in the YL data. That the reason why we choose to use the education of the parents and the consumption of the household to approximate the education required and the income provided by the occupation of the parents. More precisely, the score of actual social status of the household, denoted as $S^{H}$, is a linear combination of the level of education of the most educated parent and the consumption per capita of the household. As for the score of aspiration, these two variables have been standardized and added up with the same weight. The aspiration gap is denoted as $G^{A}$, and is then defined as:

$G^{A}=S^{A}-S^{H}$

3. Which occupations do Peruvian children aspire to?

At 8 years old, the most desired occupation is teacher, as $31 \%$ of the children want to become teacher (Table 3). Medical doctor ranks second. This result is consistent with the results of Benavides et al. (2006), whose find that Peruvian children mainly aspire to become teacher and doctor in rural area. Frequent interactions with doctors and teachers and the respect inspired by these professions may explain this result, as found by Oluigbo (1976) in the context of Nigeria. Fire-fighter and policeman are desirable occupation as well and ranks third, ahead of engineer and farmer. At 12 years old, teacher is still the most popular occupation, ahead of engineer, doctor, nurse and lawyer. Farmer is among popular occupation at age 8 but becomes unpopular as children grow up (7\% of the children 8 years want to become farmer, compared to less than 3\% when they are 12 old). Medical doctor and engineer are among the most desirable occupations for all ages. The desire to become a doctor is rather stable with age, although decreasing slightly, as the one to become nurse or fire-fighter or policeman. Engineer, accountant and lawyer become more attractive as children grow up. Finally, the number of listed occupations increases with the age of the children. Taken together, these results suggest that the aspiration window of the children get wider as they grow up. They enrich their knowledge on the labour market, on the living standards provided by these occupations, but they may also change their criteria to evaluate an occupation.

[Table 3 here] 
Another interesting result from Table 3 is the discrepancy between genders as far as the choice of the desired occupation is concerned. Girls 8 years aspire to become nurse when boys want to be fireman or policeman. At 12 years old, secretary is among the top five favorite occupations for girls, while boys prefer to become a mechanic or a lawyer. In addition, girls tend to aspire to a narrower range of occupations than boys. This evidence is well documented in the psychologist literature, where it is argued that girls believe many jobs are unsuitable for girls, whereas boys have a greater occupational understanding and see more occupational opportunities than girls (Reid and Stephens, 1985). However, this difference is reduced if we take into account the lower number of girls in the sample, and if we suppose that the number of listed occupations must be proportionate to the number of children answering to this question.

Moving to the emphasis of this paper, comparison of aspirations of indigenous and nonindigenous children shows that the top five favorite occupations of both groups are almost the same at 8 and 12 years old (Table 3). However, the ranking differs between the two groups. At 8 years old, the most desired occupation is teacher for indigenous children (41\%) while non-indigenous children most often aspire to be a doctor (31\%). These preferences stand for both sexes. At 12 years old, teacher is the preferred occupation for both groups, but the proportion of children declaring this occupation is nearly twice higher among indigenous children (31 against 18\%). Another result is that the number of occupations mentioned is smaller among indigenous children. But the difference is not significant anymore when we relate this number to the proportion of indigenous children in the sample.

By ordering the occupations mentioned as aspiration, and then by aggregating them in four groups of aspirations, as defined above, the differences between indigenous and nonindigenous children remains rather small (Table 4). First, the average aspiration score of indigenous children does not significantly differ from the one of non-indigenous children, although it is slightly lower at age 8. Second, indigenous children do not show more often low or intermediate level of aspirations. On the other hand, the share of children whose aspire to a "very high" occupation is significantly lower for indigenous children at ages 8 and 12, and indigenous children aspire significantly more often to a "high" occupation in contrast.

[Table 4 here] 
The few differences between the two groups of children at two points in time may hide large differences in the changes of the levels of aspirations as children grow. We therefore examine the level of aspiration in a dynamic way. Table 5 compares the rate of upward mobility, downward mobility and immobility between age 8 and 12 for indigenous and non-indigenous children. Here again, the differences between indigenous and non-indigenous children are small. Indigenous children lower less often their aspirations than non-indigenous children as they are growing up, and revise their aspirations upwards more frequently, but the differences are not significant.

[Table 5 here]

In contrast, indigenous children differ tremendously according to their aspiration gap (Table 4). The aspiration gap is nearly two times higher for indigenous children than for nonindigenous children. This is mainly due to the lower current social status of indigenous children. Following Ray (2006), the very large distance to fill the gap may impede indigenous children to adopt forward-looking behaviours. But at this stage, it is difficult to have a normative view on what it is a "too wide" aspiration gap.

\section{How are aspirations shaped?}

We now examine the channels by which aspirations are shaped, focusing on the role of ethnic group in this process. In particular, we aim at testing the 'internal channel hypothesis' which stipulates that ethnic belonging determines specific behaviour as a result of a "path dependence' process. Following this hypothesis, we expect that being indigenous is a significant determinant of the aspiration shaping, once external constraints are taking into account, because of an internalization of the discriminatory values conveyed by the elite since the colonial past.

\section{Empirical strategy}

The first step of our empirical strategy involves estimating the level of aspiration by introducing the ethnic group and proxies of external constraints as explanatory variables, following the equation (2):

$A_{i t}=\beta_{0}+\beta_{1} D_{i}+\beta_{2} X_{1 i t}+\beta_{3} X_{2 i t}+\epsilon_{i t}$ 
where $\mathrm{A}_{\mathrm{it}}=\left(S_{i t}^{A}, S G_{i t}^{A}\right)$ is the level of aspiration of the child $i$ at the time $t$ measured by the score of aspiration, but also by the group of aspiration to take into account potential nonlinear relationship between aspiration and ethnic group; $D_{i}$ is a dummy that takes the value one if the child is indigenous; $\mathrm{X}_{1 \text { it }}$ is a vector of variables which approach the external constraints of the child; $\mathrm{X}_{2 \mathrm{it}}$ is a vector of control variables; $\epsilon_{\mathrm{it}}$ is the residual term and $\beta_{0}, \beta_{1}, \beta_{2}$ the coefficients.

If indigenous children incorporate lower opportunities in shaping their aspiration due to racial discrimination or internalize discriminatory values concerning their ability to reach some occupations, we expect that the coefficient of being indigenous $\beta_{1}$ is significant and negative. $\mathrm{X}_{1 \mathrm{it}}$ includes economics and informational constraints. Economic constraint is measured by a wealth index ${ }^{5}$. Information constraint is measured by a dummy taking the value 1 if the child lives in a rural area, as we suppose that access to information is more limited in rural than in urban areas. Education of the parents captures both economic and information constraint, as it is highly correlated with the occupation of the parents and it determines the cultural environment of the child. Education of the parents is measured by the number of years of education of the most educated parent. We also introduce the sex of the child and the sex of the household head as control, because many studies show that aspirations are gender oriented (McMahon and Patton 1997).

Models 1 to 4 estimate the score of aspiration by using an OLS specification at age 8 (models 1 and 2), and at age 12 (models 3 and 4), first without control variables (models 1 and 3), and then with all control variables (models 2 and 4). Models 6 to 9 estimate the probability of aspiring to one of the four occupational groups, by using ordered probit models. This probability is estimated at age 8 (models 6 and 7), and at age 12 (models 8 and 9), with and without controls (models 7 and 9, models 6 and 8 respectively).

Secondly, following the psychologist literature, we consider that the development of occupational orientation and aspiration is a dynamic process. It occurs over the life course, through interaction with the social environment. It is based on growing knowledge of self and of occupations, and the reasoning about the relationship between the two that occurs with cognitive development. Gottfredson (1981) defines four stages in the development of

\footnotetext{
${ }^{5}$ For more details on the wealth index, refer to Escobal et al. 2003.
} 
occupational aspirations. Around ages 9-13 years, children enter the third stage, called the stage of orientation to social valuation, "when the more abstract self-concepts of social class and ability become important determinants of social behaviour and expectations" (p.549). Children begin to recognize prestige differences among jobs as well as social class. Some sociological studies confirm that differences by social origin in shaping aspiration grow with age, and that the awareness of social class goes hand in hand with the awareness of the ethnic discrimination (Jacobs et al. 1991). Aspirations tend to decline as children grow and understand the constraints imposed by their choices and the environment, such as ethnic barriers. Consequently, they adjust their aspirations to feasible possibilities. This phenomenon is also known as adaptive preferences in the economic literature (Elster 1985). We then estimate the equation (3):

$D A_{\text {it }}=\gamma_{0}+\gamma_{1} \mathrm{D}_{\mathrm{i}}+\gamma_{2} \mathrm{X}_{1 \mathrm{it}}+\gamma_{3} \mathrm{X}_{2 \mathrm{it}}+\mathrm{u}_{\mathrm{it}}$

Where $D A_{\text {it }}$ measures downwards adaptation of aspirations with $\left\{\begin{array}{l}D A_{i t}=1 \text { if } A_{i t}<A_{i t-1} \\ D A_{i t}=0 \text { if } A_{i t} \geq A_{i t-1}\end{array}\right.$

If the 'internal channel hypothesis' is true, we expect that indigenous children lower more their aspiration between ages 8 and 12 than non-indigenous children, and then that $\boldsymbol{\gamma}_{\mathbf{1}}$ is positive and significant (models 5 and 10). Table 6 presents the results of the estimations of models 1 to 10 .

\section{Results}

At age 8, being indigenous has a significant and negative effect on the level of aspiration, but this effect does not hold when the socio-economic background of the children is introduced (models 1, 2, 6, and 7). At age 12, we find no significant effect of the ethnic group on the level of aspiration, except in the non-linear specification (models 3, 4, and 8). But this effect disappears once controls are introduced (model 9). Hence, being indigenous is not a significant factor of the aspiration level, once the level of external constraints is controlled for. In addition, we do not find that indigenous children lower more their aspiration between ages 8 and 12 than non-indigenous children. On the contrary, we find a negative effect of being indigenous on the probability to lower aspiration between age 8 and 12 . This effect is significant as far as the aspiration level is measured by the group of aspiration (model 10). Indigenous children do not are more aware of racial discrimination when they grow up. Compared to non-indigenous children with the same external constraints, they tend to revise upward their aspiration more often. 
Economic and education background has a significant effect on the aspirations level on the other hand (models 2, 4, 7, and 9). The wealth of the household has the main effect on shaping the aspiration. This effect is positive, as the one of the education of the parents. Children who have less educated parents or who are poor lower their aspiration, whatever their age. They may exclude some prestigious occupations because they think that these occupations are out of their reach, given their actual status, or because they do not know that such occupations exist. When growing up, the role of wealth becomes more important in shaping aspiration. The children may be more conscious of the financial resources needed to pursue jobs that require high level of education while getting older. This adaptive process to economic constraint is confirmed by the negative and significant effect of the wealth index in the estimation of the probability of lowering her aspiration between age 8 and age 12 (models 5 and 10).

[Table 6 here]

Living in a rural area has a negative effect on the level of aspiration as well, in particular at age 8 (models 2, 4, 7, and 9). This result can be interpreted as a limited access to information on occupations in rural areas, as fewer occupations are represented there, in particular in remote areas. By growing up, children have easier access to media and consequently increase their knowledge on occupation and partially enlarge their aspiration window. Unlike to other previous research related to developed countries, we do not find that girls restrict their aspiration when compared to boys because they believe many jobs are not adequate for girls (McMahon and Patton 1997). We find, on the contrary, that girls have higher level of aspiration at age 8, other things being equal (models 2 and 7), but this effect disappear when girls grow up (models 4 and 9), as girls lower more their aspiration between age 8 and 12 than boys (model 5).

Taken together, these results call for the rejection of the 'internal channel hypothesis' which would lead to a lack of aspiration for indigenous children. It appears that indigenous children do not have internalized racial schemas that incorporate beliefs about occupation or about their opportunities. 
5. The effect of the aspiration gap on educational attainment

Following Ray (2006), individuals have little incentive to raise standards in case of very small or very large aspiration gap, because the distance to fill the gap is too small or too large. The question we address in this section is then whether the aspiration gap for indigenous children is too large, in so far as indigenous children becomes discouraged from providing effort at school. It may append if the effort needed to reach the education level that is required for the occupation they aspire to are too costly. "The overall journey is too long, and therefore not worth undertaking in the first place" (Ray 2006, p. 412). We then estimate the causal effect of the aspiration gap at age 8 on the school performance between age 8 and 15. Following the psychologist literature, we expect that the aspiration gap could have a different effect on the educational performance while children grow up, as children are more aware of the education level required for the occupation they aspire to. For this reason, we also estimate the effect of the aspiration gap at age 12 on the school performance between age 12 and 15 .

Children's educational performance is measured by the number of repetitions between age 8 and 15, and between age 12 and 15. We choose this variable rather than the score in language or in mathematics at age 12 and age 15, because it better reflects the evaluation by the school of the progress of the child, and consequently is more linked to the rewarding of the effort by the society. The repetition rate is higher among indigenous children than non-indigenous children (40\% versus $31 \%$ between ages 8 and 15, and 22\% versus $14 \%$ between ages 12 and $15)$.

The difficulty of establishing the sense of causality between aspirations and educational attainment lies in two potential sources of endogeneity due reverse causality and unobserved characteristics of the children. In the first case, children may adapt their aspiration to their performance at school. If they are successful at school, they may target higher educational attainment and more prestigious occupation. On the contrary, school failure may lead to downward revision of their aspiration. In the second case, aspiration levels may depends on unobserved variables that also affect educational attainment. One of these unobserved variables is ability, as children may adapt their aspiration to what they feel they are able to reach, and ability is a main factor of the educational performance. 
To address this difficulty, we rely on two strategies. First, we use the longitudinal dimension of the data to face the reverse causality problem. We observe the aspiration gap before the educational performance. We also control by the perception of the parents on the relative position of their child in her class when the child is 8 years old: "How would you rate your child's school performance? Good, average or bad?", supposing that a large part of the selfperception of the children on their ability and their past academic progress when they are 8 years old is captured by this variable. To estimate the performance of the children between age 12 and 15, we control by the score in mathematics at age 12, which is supposed to capture the school performance of the children before they are 12 years old.

We rely then on instrumental variables estimation to tackle the endogeneity issue due to unobserved characteristics. We have at our disposal an instrument that could be correlated to aspirations and independent of school performance. It is the share of the employed labour force in the district where the child is living, that has an occupation providing a low socioeconomic status. More precisely, the instrument is the share of the employed labour force in the district that has an occupation which score $S$ belongs to the group $1\left(G^{A}=1\right)$ defined in the section 2. To compute this instrument, we use the 2007 Population Census (Censos Nacionales 2007 XI de Población y VI de Vivienda), where people are asked about their main job. For each district where children of Young Lives survey are living, we impute a score to each worker following the same methodology as in section 2 , that allow us to define to which group of $\mathrm{G}^{\mathrm{A}}$ the worker belongs. ${ }^{6}$ This instrument reflects the concept of aspiration window defined by Ray and consequently is supposed to shape the aspiration gap. On the other hand, it is independent from repetition, at repetition rate is supposed to be not correlated with district characteristics because it well acknowledged that the teacher adapted to the level of the classroom when evaluating the pupils in such a way as to maintain approximately the same normal distribution of marks from year to year (De Landsheere 1980). Repetition reflects then the effort of the children relatively to her classmate, and then it independent from the context at the district level.

We also partially control for unobserved ability by introducing the score of Raven test at age 8. This test is an intelligence test, not an achievement test, and it does not rely on language to determine cognitive abilities. We also introduce an anthropometric measurement of the child

\footnotetext{
${ }^{6}$ These groups are the same than for aspiration. It means that they are defined as the quartiles of the score from all the occupations listed by the children in R1, R2 and R3 when they are asked about their aspirations.
} 
at age 8 to control the health status of the child. This variable takes the value 1 if the child is malnourished (height-for-age $\mathrm{z}-<-2$ ). The other controls of the models are the same than in model (2).

The equations we estimate are then:

$E_{i t}=\beta_{0}+\beta_{1} A_{i(t-1)}+\beta_{2} X_{i(t-1)}+\epsilon_{i t}$

$A_{i(t-1)}=\gamma_{0}+\gamma_{1} I_{i(t-1)}+u_{i}$

where $E_{i t}$ is the educational outcome of child $i$ at time $t, I_{i(t-1)}$ is the instrumental variable.

Models 11 to 13 estimate the probability of repeating at least one year between age 8 and age 15 by the aspiration gap at age 8 and controls defined earlier. Models 14 to 22 estimate the probability of repeating at least one year between age 12 and age 15 by the aspiration gap at age 12 and controls defined earlier. Models 11, 12, 14, and 15 rely on a probit. Models 112 and 14 introduce interaction between the aspiration gap and the ethnic dummy to test whether the effect of the aspiration gap is different for the indigenous children than for the nonindigenous children. Models 13 and 16 are based on instrumental variables. Table 7 shows the results of these estimations.

In all the models, the aspiration gap has a significant effect on the probability to repeat a class, with the exception of the model 14. However, the sense of the effect differs according to the models. It is negative in the model 11 based on a probit specification without interaction, meaning that children who have very high aspiration compared to their current social status have a lower probability to repeat, other things being equal. However, looking at the results of models 12 and 15 which include interactions, it appears that this negative effect is driven by the effect of aspiration gap for non-indigenous children. Indeed, aspiration gap has a reverse effect for indigenous and non-indigenous children. For indigenous children, the highest the aspiration gap, the highest the probability to repeat a year. However, the positive effect of aspiration gap on the probability to repeat is significant only between ages 12 and 15 (model 15). It means that indigenous children may not associate an educational level to the occupation they aspire to in their early age.

Moving to the models 13 and 16, which are best designed to limit the endogeneity bias, the results shows a positive and significant effect of the aspiration gap on the probability to repeat. This result is consistent with the ones of the others models as far as we consider the 
local average treatment effect (LATE). As highlighted by Imbens and Angrist (1994), instrumental variables gives the effect of the aspiration gap on repetition for those whose aspiration gap is impacted by the share of workers in the district who have an occupation providing a low socio-economic status, or in other words, for those who integrate in their aspiration window people who are on at the bottom of the social ladder. And indigenous children are more likely to do it than non-indigenous children, as shown by the results of the regression of the aspiration gap on the instrument (share of workers in the district with low socio-economic status) and interaction between ethnic dummy and the instrument (not reported).

To conclude, our estimates suggest that a large aspiration gap at age 12 has a negative impact on the educational outcomes of indigenous children. Consequently, the highest distance for indigenous children to fill the gap between the occupation they aspire to and their current socio-economic status appears to discouraged them from providing effort at school, as the effort needed to reach this occupation are too costly.

\section{Conclusion}

In this paper, we examine whether aspirations failure is one of the mechanisms of intergenerational poverty trap for indigenous people. To address the question, we rely on the longitudinal Young Lives data, focusing on the older cohort, surveyed at 8, 12 and 15 years old, in 2002, 2006 and 2009 respectively. We find that aspiration failure is a channel of inequality persistence between indigenous and non-indigenous people. Indeed, in addition to highest economics constraints, we show that indigenous children face an aspiration failure that affects their decision-making process and leads to underinvestment in education.

The aspiration failure do not takes the form of a lack of aspiration. Aspirations of indigenous children are quite similar to those of non-indigenous children once the level of external constraints is controlled for. However, indigenous children differ tremendously according to their aspiration gap, that measure the distance between the socio-economic status they aspire to reach and their current one. The distance they have to cover to fill this gap is nearly two times higher than non-indigenous children. But the difference is driven by the highest external constraints of indigenous children. This result calls for the rejection of the hypothesis that indigenous children have internalized racial schemas that incorporate beliefs about occupation 
or about their opportunities, and which would lead to a lack of aspiration for indigenous children.

In addition, this paper shows that large aspiration gap impede indigenous children to adopt forward-looking behaviours, such as investment in education. This paper adopts an original strategy to identify the causal effect of aspiration gap on educational outcomes. It relies on an instrumental variable calculated using the Population Census, that is the proportion of the workers with low socio-economic status in the district where the child is living. Our estimates suggest that the aspiration gap for indigenous children is too large, in so far as it has a positive effect on the probability to repeat a grade. The disincentive effect of large aspiration gap on the effort provided at school becomes more important while the indigenous children grow up, as they may be more aware of the distance between their aspiration and their current status.

Consequently, policy that aims at alleviating the exogenous socio-economic constraints faced by indigenous people will contribute to bridge their aspiration gap, and therefore will have an incentive effect on the effort they provide to improve their social-economic status. The reduction of the aspiration gap then has a multiplier effect on policy which seeks to break the vicious circle of poverty for indigenous people. 


\section{References}

Acemoglu, D., Johnson, S., \& Robinson, J. (2002). Reversal of Fortune: Geography and Institutions in the Making of the Modern World Income Distribution. The Quarterly Journal of Economics, 117(4), 1231-1294.

Adams, N., \& Valdivia, N. (1991). Los nuevos empresarios. Etica de migrantes y formación de empresas en Lima. Lima: IEP.

Ames, P. (2012). Language, culture and identity in the transition to primary school: challenges to indigeneous children's rights to education in Peru. International Journal of Educational Development, $32(3), 454-462$.

Ansión, J., Lazarte, A., Matos, S., Rodriguez, J., \& Vega-Centeno, P. (1998). Educación : la mejor herencia. Decisiones educativas y expectativas de los padres de familia. Una aproximación empírica. Lima: Pontifica Universidad Católica del Perú.

Appadurai, A. (2004). The capacity to aspire. In M. Walton \& V. Rao (Eds), Culture and Public Action (59-84). Stanford, CA: Stanford University Press.

Barrón, M. (2005). Cuánto cuesta ser provinciano a un empleado de Lima Metropolitana: Una aproximación mediante Propensity Score Matching. Observatorio de la Economia Latinoamericana, Grupo Eumed.net (Universidad de Malaga), issue 47.

Barrón, M. (2008). Exclusion and Discrimination as Sources of Inter-Ethnic Inequality in Peru. Economía, 31(61),51-80.

Benavides, M., Olivera, I. \& Mena M. (2006). De papás y mamas a hijos e hijas: las aspiraciones sobre el futuro y rol de las familias en las actividades escolares en el Perú . In M. Benavides (Ed.) Los desafios de la escolaridad en el Perú (157-201). Lima: GRADE.

Bernard, T., Dercon S., \& Tafesse A.S.0 (2011). Beyond Fatalism-an Empirical Exploration of Selfefficacy and Aspirations Failure in Ethiopia. CSAE Working Paper 2011-03.

Bernard T., \& Tafesse A.S. (2012). Measuring Aspirations: Discussion and Example from Ethiopia. IFPRI Discussion Paper 01190.

Bigler, R.S., Averhart, C.J., \& Liben, L.S. (2003). Race and the Workforce: Occupational Status, Aspirations, and the Steeotyping Among African American Children. Developmental Psychology, 39(3), 572-580.

Bourdieu, P. (1997). Méditations pascaliennes. Paris: Seuil.

Camfield, L., Masae A., Mc Gregor. A., \& Promphaking B. (2012). Culture of Aspiration and Poverty? Aspirational Inequalities in Northeast and Southern Thailand. DEV International Development Working Paper 38, University of East Anglia.

Cosby, A.G., \& Picou, J.S. (1973). Structural Models and Occupational Aspirations: Black-White Variations Among Deep-South Adolescents. Journal of Vocational Behavior, 3(1), 1-14.

Cueto, S. (2007). Las evaluaciones nacionales e internacionales de rendimiento escolar en el Perú: balance y perspectivas. En Grupo de Análisis para el Desarrollo (Ed.). Investigación, Políticas y Desarrollo en el Perú. (405-455). Lima: GRADE. 
Cueto, S., Guerrera, G. Leon J., Seguin E., \& Munoz I. (2009). Explaining and overcoming marginalization in education: a focus on ethnic/language minorities in Peru, Background paper prepared for the Education for All Global Monitoring Report 2010.

De Landsheere, G. (1980). Evaluation continue et examen: Précis de docimologie. Brussels: Editions Labor.

Dercon, S., \& Krishnan, P. (2009). Poverty and the Psychosocial Competencies of Children: Evidence from the Young Lives Sample in Four Developing Countries. Children, Youth and Environments, 19(2), 138-163.

De Soto, H. (1986). El otro sendero. La revolución informal. Lima: El Barranco.

Duflo, E. (2006). Poor but Rational? In A. V. Banerjee, Bénabou, R., \& Mookherjee, D., (Eds), Understanding Poverty (367-378). New York: Oxford University Press.

Elster, J. (1985), Sour Grapes: studies in the subversion of rationality. Cambridge: Cambridge University Press.

Engerman, S.L., \& Sokoloff, K.L. (2005). Colonialism, Inequality, and Long-run Paths of Development. NBER Working paper $\mathrm{N}^{\circ} 11057$.

Escobal, J., Lanata, C., Madrid, S., Penny, M., Saavedra, J., Suarez, P., Verastegui, H., Villar, E., \& Huttly, S. (2003). Young Lives Preliminary Country Report: Peru. Oxford, UK: Young Lives.

Escobal, J., \& Ponce C. (2007). Economic Opportunities for Indigenous Peoples in Rural and Urban Peru. In: Conference Edition: Economic Opportunities for Indigenous Peoples in Latin America. Washington DC: World Bank.

Escobal, J., \& Flores, E. (2008). An Assessment of the Young Lives Sampling Approach in Peru. Young Lives Technical Note $\mathrm{n}^{\circ} 3$.

Figueroa, A. (2006). El problema del empleo en una sociedad sigma. CISEPA Working Paper $\mathrm{N}^{\circ} 249$. Lima: Pontificia Universidad Católica del Perú.

Ganzeboom, H.B., \& Treiman, D. (1996). Internationally Comparable Measures of Occupational Status for the 1988 International Standard Classification of Occupations. Social Science Research. $25,201-239$.

Glick, J. E., \& White, M. J. (2004). Parental Aspirations and Post-Secondary School Participation among Immigrant and Native Youth in the United States. Social Science Research, 33, 272-299.

Goldenberg, C., Gallimore, R., Rees, L., \& Garnier, H. (2001). Cause or effect? A longitudinal study of immigrant latino parents' aspirations and expectations, and their children's school performance. American Educational Research Journal, 38(3), 547-582.

Golte, J., \& Adams, N. (1987). Los caballos de Troya de los conquistadores. Estrategias campesinas para la conquista de la gran Lima. Lima: IEP.

Gottfredson, L. S. (1981). Circumscription and compromise: A developmental theory of occupational aspirations. Journal of Counseling Psychology, 28(6), 545-579. 
Henríquez, N. (1995). La sociedad diversa, hipótesis y criterios sobre la reproducción social. In G. Portocarrero \& M. Valcarcel (Eds.), El Perú frente al Siglo XXI. Lima: Pontifica Universidad Católica del Perú Fondo Editorial.

Hoff, K., \& Pandey, P. (2006). Discrimination, Social Identity, and Durable Inequalities. American Economic Review, 96(2), 206-211.

Hubert, L. (1997). Etnicidad y economía en el Perú. IEP, Documento de Trabajo nº3.

Ibrahim, S. (2011) Poverty, Aspirations and Wellbeing: Afraid to aspire and Unable to Reach a better Life - Voices from Egypt. BWPI Working Paper no. 141, University of Manchester.

Imbens G.W., Angrist, D. (1994). Identification and Estimation of Local Average Treatment Effects. Econometrica, 62(2), 467-475.

Instituto Nacional de Estadística e Informática (INEI). (2011). Perú: Perfil de la Pobreza por departamentos, 2001-2010. Lima :INEI.

Jacobs, J.A., Karen, D., \& McClelland, K. (1991). The Dynamics of Young Mens Career Aspirations. Sociological Forum, 6(4), 609-639.

Kao, G., \& Tienda, M. (1998). Educational Aspirations of Minority Youth. American Journal of Education, 106(3), 349-384.

Kuvlesky, W., \& Patella, V. (1971). Degree of Ethnicity and Aspirations for Upward Social Mobility Among Mexican American Youth. Journal of Vocational Behavior, 1(3), 231-244.

Mac Isaac, D. (1994). Peru. In G. Psacharopoulos \& H. Patrinos (eds.), Indigenous People and Poverty in Latin America: An Empirical Analysis (165-204). Washington, D.C.: The World Bank.

MacMahon, M., \& Patton, W. (1997). Gender differences in children and adolescents' perceptions of influences on their career development. School Counselor, 44, 368-376.

Mahoney, J. (2003). Long-run Development and the Legacy of Colonialism in Spanish America. American Journal of Sociology, 109(1), 50-106.

Matos Mar, J. (1984). Desborde popular y crisis del Estado. El nuevo rostro del Perú en la década de 1980. Lima: IEP.

Mendoza, O. (1997). Las redes sociales y el crecimiento de las pequeñas empresas en Gamarra, 19801996. In Balbi (Eds.), Aspiraciones, reconocimiento y ciudadanía en los noventa (29-55). Lima: Pontificia Universidad Católica del Perú.

Mookherjee, D., Napel, S., \& Ray, D. (2010). Aspirations, Segregation, and Occupational Choice. Journal of European Economic Association, 8(1), 139-168.

Ñopo, H., Saavedra, J., \& Torero M. (2004). Ethnicity and Earnings in Urban Peru. IZA Discussion Papers 980. Bonn, Germany: Institute for the Study of Labor.

Oluigbo, N.O. (1976). Patterns of Occupational Choice and Aspiration in Conditions of Economic and Technological Underdevelopment. Journal of Vocational Behavior, 8(2), 133-44.

Page, L. (2005). From social inequalities to educational inequalities: educational choices and prospect theory. Revue économique, 56(3), 615-623. 
Page, L., Levy Garboua, L., \& Montmarquette, C. (2007). Aspiration levels and educational choices : An experimental study. Economics of Education Review, 26(6), 747-757.

Pasquier-Doumer L. (2002). La evolución de la movilidad educacional intergeneracional en el Perú desde hace un siglo. Bulletin de l'Institut Français d'Etudes Andines, 31(3), 429-471.

Piketty, T. (1998). Self-fulfilling beliefs about social status. Journal of Public Economics, 70(1), 115132.

Qian, Z., \& Blair, S.L. (1999). Racial/Ethnic Differences in Educational Aspirations of High School Seniors. Sociological Perspectives, 42(4), 605-625.

Rao, V., \& Walton M. (2004) Culture and Public Action. Stanford: Stanford University Press.

Ray, D. (2006). Aspirations, Poverty and Economic Change. In A. Banerjee, R. Bénabou, \& D. Mookherjee (eds), Understanding Poverty. London: Oxford University Press.

Reid, P.T., \& Stephens, D. S. (1985). The roots of future occupations in childhood: A review of the literature on girls and careers. Youth and Society, 16(3), 267-288.

Reissman, L. (1953). Levels of Aspiration and Social Class, American Sociological Review, 18(3), 233-242.

Roemer, J.E. (1998). Equality of Opportunity. Cambridge: Harvard University Press.

St-Hilaire, A. (2002). The Social Adaptation of Children of Mexican Immigrants: Educational Aspirations Beyond Junior High School. Social Science Quarterly, 83(4), 1026-1043.

Sen, A. K. (2004). 'How does culture matter?' in V. Rao and M. Walton (eds.), Culture and Public Action, Stanford, CA: Stanford University Press.

Trivelli, C. (2005). Una mirada cuantitativa a la situación de pobreza de los hogares indígenas en el Perú. Economía, 28(55-56), 83-158.

Zhang, Y., Haddad, E., Torres, B., \& Chan, C. (2011). The Reciprocal Relationships Among Parents' Expectations, Adolescents' Expectations, and Adolescents' Achievement: A Two-Wave Longitudinal Analysis of the NELS Data. Journal of Youth and Adolescence, 40(44), 479 - 489. 
Table 1: Characteristics of the groups of occupational aspirations

\begin{tabular}{|lccccc|}
\hline & $\begin{array}{c}\text { \# Occu- } \\
\text { pations }\end{array}$ & Mean & Std. Dev. & Min & Max \\
\hline Low aspirations $\left(S G^{A}=1\right)$ & & & & & \\
Average income $(\mathrm{S} /)$. & 14 & 5000 & 2197 & 1964 & 10286 \\
Average years of education & 14 & 8.0 & 1.2 & 5.2 & 9.4 \\
Standardized score $S^{A}$ & 14 & -1.91 & 0.46 & -2.93 & -1.40 \\
\hline Intermediate aspirations $\left(S G^{A}=2\right)$ & & & & \\
Average income $(\mathrm{S} /)$. & 14 & 7150 & 2382 & 4155 & 11798 \\
Average years of education & 14 & 10.9 & 1.5 & 8.6 & 13.4 \\
Standardized score $S^{A}$ & 14 & -0.85 & 0.46 & -1.35 & 0.05 \\
\hline High aspirations $\left(S G^{A}=3\right)$ & & & & & \\
Average income $(\mathrm{S} /)$. & 14 & 12564 & 2523 & 8836 & 16051 \\
Average years of education & 14 & 14.0 & 1.1 & 11.9 & 15.7 \\
Standardized score $S^{A}$ & 14 & 0.49 & 0.31 & 0.06 & 1.16 \\
\hline Very high aspirations $\left(S G^{A}=4\right)$ & & & & \\
Average income $(\mathrm{S} /)$. & 13 & 29051 & 18242 & 12569 & 71724 \\
Average years of education & 13 & 16.2 & 0.5 & 15.0 & 16.9 \\
Standardized score $S^{A}$ & 13 & 2.44 & 1.31 & 1.22 & 5.63 \\
\hline
\end{tabular}

Source: Young lives R1, R2 surveys, ENHAO 2006. Authors' calculation. 
Table 2: Distribution of occupations within aspirations groups (\%)

\begin{tabular}{|c|c|c|c|}
\hline \multicolumn{2}{|l|}{ At 8 years old } & \multicolumn{2}{|l|}{ At 12 years old } \\
\hline Low aspirations (group 1) & 12.2100 & Total & 4.7100 \\
\hline Retail trader & 1.2 & Cook & 1.2 \\
\hline Stall saleperson & 4 & Retail trader & 9.5 \\
\hline Agricultural worker & 53.5 & Agricultural worker & 47.3 \\
\hline Fishery worker & 0.5 & Animal producer & 5.3 \\
\hline Handicraft worker in textile & 4.5 & Taylor & 1.8 \\
\hline Backer & 0.5 & Domestic & 26.3 \\
\hline Taylor & 0.5 & Construction unskilled worker & 8.5 \\
\hline Bricklayer & 3.7 & & \\
\hline Street vendor & 0.5 & & \\
\hline Domestic & 19.4 & & \\
\hline Cleaner & 4.9 & & \\
\hline Construction unskilled worker & 7 & & \\
\hline Intermediate aspirations (group 2) & $5.4 \quad 100$ & Total & 13.7100 \\
\hline Receptionist & 1.1 & Decorator & 3.3 \\
\hline Sport player & 15.4 & Sport player & 10.3 \\
\hline Secretary & 11 & Secretary & 2 \\
\hline Mechanic & 9.4 & Waiter & 0.4 \\
\hline Carpenter & 5.6 & Hairdresser & 0 . \\
\hline Construction worker & 2.2 & Mechanic & 40.6 \\
\hline Driver & 54.3 & Electrician & 3. \\
\hline Unskilled worker in mining & 1.1 & Painter & 1.7 \\
\hline & & Carpenter & 1 . \\
\hline & & Construction worker & U. \\
\hline & & Driver & 8. \\
\hline & & Transport worker & 3.2 \\
\hline High aspirations (group 3) & $\begin{array}{lll}51.6 & 100\end{array}$ & Total & 43.3100 \\
\hline Armed forces & 0.8 & Military officer & 0.1 \\
\hline Chief executive & 1.4 & Armed forces & 1.2 \\
\hline Teacher & 59.5 & Teacher & 55.2 \\
\hline Journalist & 0.2 & Journalist & 0. \\
\hline Artist & 4 & Artist & 4.4 \\
\hline Religious professional & 0.5 & Designer & 0.4 \\
\hline Designer & 0.1 & Information technician & 0.1 \\
\hline Information technician & 0.8 & Nursing professional & 25.4 \\
\hline Nursing professional & 11.9 & Accounting associate & 0. \\
\hline Fire-fighter Police officer & 20.7 & Guide & 0.7 \\
\hline & & Fire-fighter Police officer & 11.2 \\
\hline Very high aspirations (group 4) & 30.8100 & Total & 38.3100 \\
\hline Physicist & 0.2 & Business manager & 2.9 \\
\hline Architect & 0.2 & Physicist & 1. \\
\hline Engineer & 22 & Architect & 2.5 \\
\hline Biologist & 0.2 & Engineer & 35.1 \\
\hline Medical doctor & 70.7 & Biologist & 1.2 \\
\hline Veterinarian & 3.3 & Medical doctor & 30.3 \\
\hline Accountant & 0.2 & Veterinarian & \\
\hline Lawyer & 2.6 & University teacher & 0.7 \\
\hline Economist & 0.3 & Accountant & 3.7 \\
\hline Aircraft pilot & 0.4 & Lawyer & 16.8 \\
\hline & & Economist & 2. \\
\hline & & Psychologist & 0.5 \\
\hline & & Aircraft pilot & 0.2 \\
\hline Total & 100 & Total & 100 \\
\hline Nobs & 615 & Nobs & 615 \\
\hline
\end{tabular}

Source: Young lives R1, R2. Authors' calculation. 
Table 3: Distribution of occupational aspirations by age, sex and ethnic group (\%)

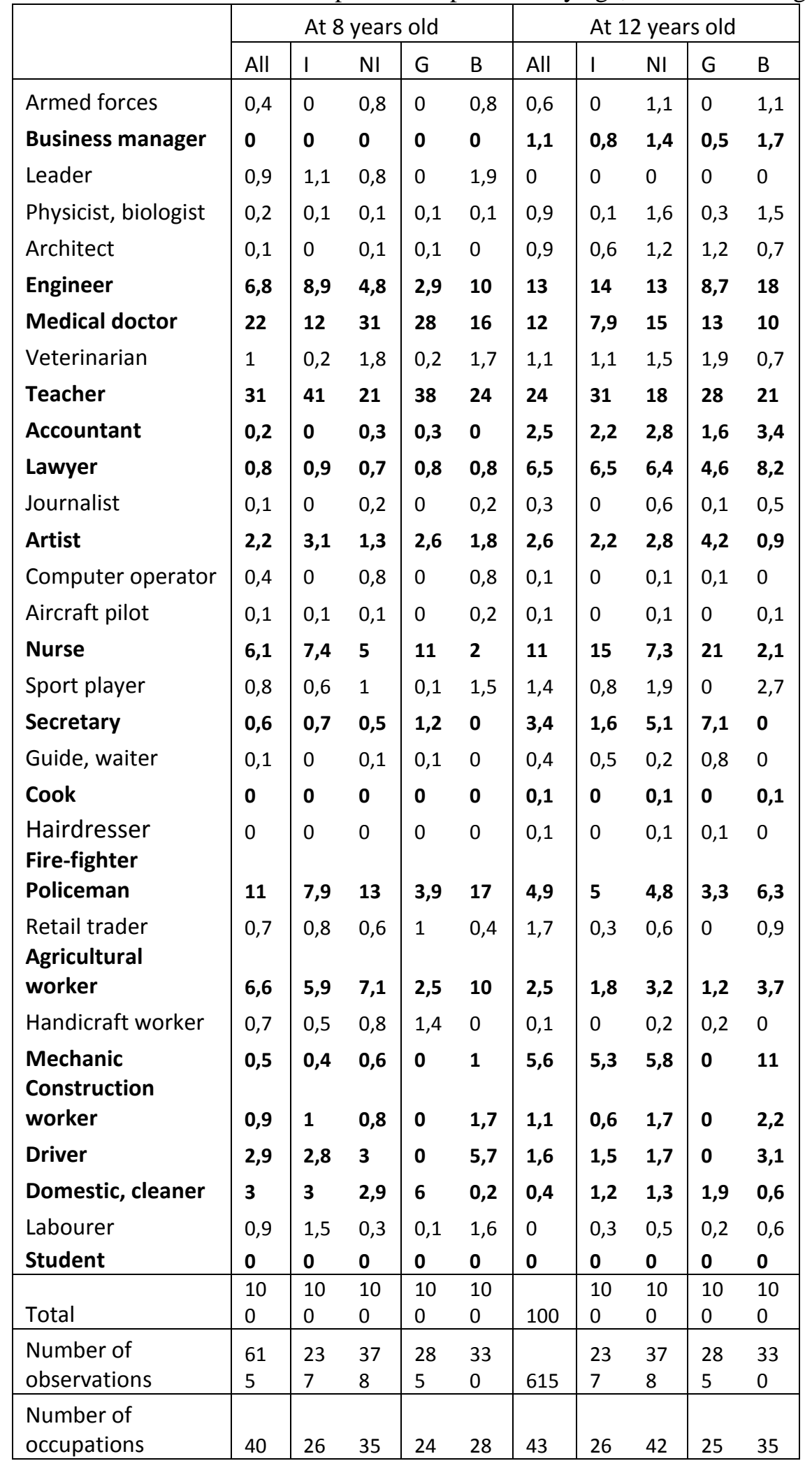

Source: Young lives R1, R2 surveys. Authors' calculation.

Note: I: Indigenous; NI: Non Indigenous; B: Boys; G: Girls. Number of occupations is the number of different occupations listed by the children and recoded using the 3-digit International Standard Classification of Occupation 2008 (ISCO-08). 
Table 4: Distribution of occupational aspirations and average aspiration gap, by age and ethnic group

\begin{tabular}{|l|c|c|c|c|c|c|}
\hline \multirow{2}{*}{} & \multicolumn{3}{|c|}{ At 8 years old } & \multicolumn{3}{c|}{ At 12 years old } \\
\cline { 2 - 7 } & $\mathrm{I}$ & $\mathrm{NI}$ & $\mathrm{Diff}$ & $\mathrm{I}$ & $\mathrm{NI}$ & Diff \\
\hline Average aspiration score & 0.7 & 0.8 & $\mathrm{NS}$ & 1.0 & 1.0 & NS \\
\hline Aspirations groups (\%) & & & & & & \\
Low & 12.0 & 12.2 & $\mathrm{NS}$ & 3.6 & 5.8 & NS \\
Intermediate & 5.2 & 5.6 & $\mathrm{NS}$ & 10.4 & 16.7 & $*$ \\
High & 60.5 & 43.3 & $* * *$ & 53.2 & 34.1 & $* * *$ \\
Very high & 22.2 & 38.8 & $* * *$ & 32.8 & 43.3 & $* *$ \\
Total & 100 & 100 & & 100 & 100 & \\
\hline Average aspiration gap & 1.5 & 0.8 & $* * *$ & 1.8 & 1.0 & $* * *$ \\
\hline N obs & 237 & 378 & & 237 & 378 & \\
\hline
\end{tabular}

Source: Young lives R1, R2 surveys. Authors' calculation.

Note: I: Indigenous; NI: Non Indigenous; Diff column tests the significance of the differences between the I and NI proportion/mean; NS means that the difference is non-significant, *, **, *** that the difference is significant at the 10,5 , and $1 \%$ levels, respectively.

Table 5: Indicators of aspirations mobility between age 8 and 12 and age 8 by ethnic group

\begin{tabular}{|l|ccc|ccc|}
\hline \multirow{2}{*}{$(\%)$} & \multicolumn{5}{|c|}{ Mobility from age 8 to 12 } \\
\cline { 2 - 7 } & \multicolumn{4}{|c|}{ Score differential } & Group differential \\
\hline \multirow{4}{*}{ Upward mobility } & 42.4 & 40 & NS & 31.6 & 28.4 & NS \\
\cline { 2 - 7 } Downward mobility & 31.5 & 40 & NS & 19 & 29 & NS \\
Immobility & 26.1 & 20 & NS & 49.4 & 42.6 & NS \\
Total & 100 & 100 & & 100 & 100 & \\
\hline
\end{tabular}

Source: Young lives R1, R2 surveys. Authors' calculation.

Note: See table 4. 
Table 6: Estimation of the scores of aspiration and the groups of aspiration at ages 8 and 12

\begin{tabular}{|c|c|c|c|c|c|c|c|c|c|c|}
\hline \multirow{2}{*}{$\begin{array}{r}\begin{array}{r}\text { Dependent } \\
\text { variables }\end{array} \\
\begin{array}{l}\text { Models } \\
\text { Independent } \\
\text { variables }\end{array}\end{array}$} & \multicolumn{2}{|c|}{$\begin{array}{c}\text { Score of aspiration } \\
\text { Age } 8\end{array}$} & \multicolumn{2}{|c|}{$\begin{array}{c}\text { Score of aspiration } \\
\text { Age } 12\end{array}$} & \multirow[t]{2}{*}{$\begin{array}{c}\text { Down- } \\
\text { ward } \\
\text { score } \\
\text { between } \\
\text { ages } 8 \\
\text { and } 12 \\
(5)\end{array}$} & \multicolumn{2}{|c|}{$\begin{array}{c}\text { Group of aspiration } \\
\text { Age } 8\end{array}$} & \multicolumn{2}{|c|}{$\begin{array}{c}\text { Group of aspiration } \\
\text { Age } 12\end{array}$} & \multirow{2}{*}{$\begin{array}{c}\text { Downwar } \\
\text { d group } \\
\text { between } \\
\text { ages } 8 \text { and } \\
12 \\
(10) \\
\text { Probit }\end{array}$} \\
\hline & OLS & OLS & $\begin{array}{l}\text { (3) } \\
\text { OLS }\end{array}$ & $\begin{array}{l}\text { (4) } \\
\text { OLS }\end{array}$ & & $\begin{array}{c}(6) \\
\text { Ordered } \\
\text { probit }\end{array}$ & $\begin{array}{c}(7) \\
\text { Ordered } \\
\text { probit }\end{array}$ & $\begin{array}{c}(8) \\
\text { Ordered } \\
\text { probit }\end{array}$ & $\begin{array}{c}(9) \\
\text { Ordered } \\
\text { probit }\end{array}$ & \\
\hline $\begin{array}{l}\text { Indigenous } \\
\text { child }\end{array}$ & $\begin{array}{l}-0.186^{*} \\
(0.116)\end{array}$ & $\begin{array}{c}0.050 \\
(0.119)\end{array}$ & $\begin{array}{l}-0.138 \\
(0.105)\end{array}$ & $\begin{array}{c}0.106 \\
(0.109)\end{array}$ & $\begin{array}{l}-0.092 \\
(0.113)\end{array}$ & $\begin{array}{c}-0.283^{* * *} \\
(0.092)\end{array}$ & $\begin{array}{l}-0.086 \\
(0.100)\end{array}$ & $\begin{array}{l}-0.141^{*} \\
(0.091)\end{array}$ & $\begin{array}{l}0.117 \\
(0.102)\end{array}$ & $\begin{array}{c}-0.237^{*} \\
(0.123)\end{array}$ \\
\hline $\begin{array}{l}\text { Years of edu } \\
\text { of the } \\
\text { most } \\
\text { educated } \\
\text { parent }\end{array}$ & & $0.038^{*}$ & & $0.056^{* * * *}$ & 0.005 & & $0.045^{* *}$ & & $0.046 * * *$ & 0.008 \\
\hline Rural & & $\begin{array}{c}-0.361^{* *} \\
(0.166)\end{array}$ & & $\begin{array}{l}-0.258^{*} \\
(0.159)\end{array}$ & $\begin{array}{l}-0.172 \\
(0.150)\end{array}$ & & $\begin{array}{c}-0.297^{* *} \\
(0.129)\end{array}$ & & $\begin{array}{l}-0.245^{*} \\
(0.134)\end{array}$ & $\begin{array}{l}-0.208 \\
(0.158)\end{array}$ \\
\hline Wealth index & & $\begin{array}{c}0.750 * * \\
(0.336)\end{array}$ & & $\begin{array}{c}0.824 * * \\
(0.380)\end{array}$ & $\begin{array}{c}-0.714 * * \\
(0.316)\end{array}$ & & $\begin{array}{c}0.688 * * \\
(0.292)\end{array}$ & & $\begin{array}{c}1.080 * * * \\
(0.324)\end{array}$ & $\begin{array}{c}-1.246 * * * \\
(0.338)\end{array}$ \\
\hline Girl & & $\begin{array}{c}0.507 * * * \\
(0.105)\end{array}$ & & $\begin{array}{l}-0.057 \\
(0.100)\end{array}$ & $\begin{array}{c}0.262 * * \\
(0.105)\end{array}$ & & $\begin{array}{c}0.356 * * * \\
(0.093)\end{array}$ & & $\begin{array}{l}-0.017 \\
(0.092)\end{array}$ & $\begin{array}{c}0.118 \\
(0.113)\end{array}$ \\
\hline $\begin{array}{l}\text { Household } \\
\text { head } \\
\text { is a female }\end{array}$ & & $\begin{array}{c}-0.284 * * \\
(0.138)\end{array}$ & & $\begin{array}{l}-0.008 \\
(0.129)\end{array}$ & $\begin{array}{l}-0.042 \\
(0.134)\end{array}$ & & $\begin{array}{l}-0.196^{*} \\
(0.118)\end{array}$ & & $\begin{array}{l}0.025 \\
(0.121)\end{array}$ & $\begin{array}{l}-0.104 \\
(0.148)\end{array}$ \\
\hline Constant & $\begin{array}{c}0.953 * * * \\
(0.069)\end{array}$ & $\begin{array}{c}0.033 \\
(0.262)\end{array}$ & $\begin{array}{c}1.192 * * * \\
(0.069)\end{array}$ & $\begin{array}{c}0.266 \\
(0.292)\end{array}$ & $\begin{array}{l}-0.075 \\
(0.232)\end{array}$ & & & & & $\begin{array}{l}-0.032 \\
(0.245)\end{array}$ \\
\hline Constant cut 1 & & & & & & $\begin{array}{c}-1.420 * * * \\
(0.082)\end{array}$ & $\begin{array}{c}- \\
0.618^{* * * *} \\
(0.212)\end{array}$ & $\begin{array}{c}- \\
1.812^{* * * *} \\
(0.100)\end{array}$ & $\begin{array}{c}- \\
0.916^{* * * *} \\
(0.258)\end{array}$ & \\
\hline Constant cut 2 & & & & & & $\begin{array}{c}-1.123^{* * * *} \\
(0.074)\end{array}$ & $\begin{array}{l}-0.297 \\
(0.208)\end{array}$ & $\begin{array}{c}- \\
0.982 * * * \\
(0.075)\end{array}$ & $\begin{array}{l}-0.040 \\
(0.248)\end{array}$ & \\
\hline Constant cut 3 & & & & & & $\begin{array}{c}0.192 * * * \\
(0.063)\end{array}$ & $\begin{array}{c}1.111 * * * \\
(0.208)\end{array}$ & $\begin{array}{c}0.004 \\
(0.064)\end{array}$ & $\begin{array}{c}1.019 * * * \\
(0.248)\end{array}$ & \\
\hline $\begin{array}{l}\text { Observations } \\
\text { R-squared }\end{array}$ & $\begin{array}{c}609 \\
0.004\end{array}$ & $\begin{array}{c}609 \\
0.101\end{array}$ & $\begin{array}{c}609 \\
0.003\end{array}$ & $\begin{array}{c}609 \\
0.092\end{array}$ & 609 & 609 & 609 & 609 & 609 & 609 \\
\hline $\begin{array}{l}\text { log likelihood } \\
\text { pseudo-R- } \\
\text { squared }\end{array}$ & -1055.03 & -1023.78 & -1020.66 & -992.24 & $\begin{array}{c}-391.42 \\
0.016\end{array}$ & $\begin{array}{c}-678.12 \\
0.007\end{array}$ & $\begin{array}{c}-646.15 \\
0.054\end{array}$ & $\begin{array}{c}-681.69 \\
0.002\end{array}$ & $\begin{array}{c}-643.81 \\
0.057\end{array}$ & $\begin{array}{c}-327.85 \\
0.029\end{array}$ \\
\hline
\end{tabular}

Source: Young lives R1, R2 and R3 surveys. Authors' calculation. 
Table 7: Estimation of repetition between ages 8 and 12 and between ages 12 and 15

\begin{tabular}{|c|c|c|c|c|c|c|}
\hline \multirow{3}{*}{$\begin{array}{r}\text { Dependent variables } \\
\text { Models } \\
\text { Independent variables } \\
\end{array}$} & \multicolumn{3}{|c|}{ Repetition between ages 8 and 15} & \multicolumn{3}{|c|}{ Repetition between ages 12 and 15} \\
\hline & (11) & (12) & (13) & (14) & (15) & (16) \\
\hline & Probit & Probit & IV probit & Probit & Probit & IV probit \\
\hline Aspiration gap age 8 & $\begin{array}{c}-0.079 * * \\
(0.031)\end{array}$ & & $\begin{array}{c}0.458 * * * \\
(0.133)\end{array}$ & & & \\
\hline Aspiration gap age 12 & & & & $\begin{array}{l}0.008 \\
(0.049)\end{array}$ & & $\begin{array}{c}0.565^{* * * *} \\
(0.104)\end{array}$ \\
\hline Indigenous child & $\begin{array}{l}-0.118 \\
(0.127)\end{array}$ & $\begin{array}{c}-0.308 * * \\
(0.142)\end{array}$ & $\begin{array}{l}-0.137 \\
(0.098)\end{array}$ & $\begin{array}{l}-0.060 \\
(0.139)\end{array}$ & $\begin{array}{l}-0.317^{*} \\
(0.171)\end{array}$ & $\begin{array}{l}-0.177 * \\
(0.095)\end{array}$ \\
\hline Nind*Aspiration gap & & $\begin{array}{c}-0.154 * * * \\
(0.042)\end{array}$ & & & $\begin{array}{l}-0.041 \\
(0.048)\end{array}$ & \\
\hline Ind*Aspiration gap & & $\begin{array}{l}0.052 \\
(0.053)\end{array}$ & & & $\begin{array}{c}0.155^{* * *} \\
(0.070)\end{array}$ & \\
\hline Raven score age 8 & $\begin{array}{c}-0.022^{* * * *} \\
(0.008)\end{array}$ & $\begin{array}{c}-0.025 * * * \\
(0.008)\end{array}$ & $\begin{array}{c}-0.022^{* * *} \\
(0.008)\end{array}$ & $\begin{array}{l}-0.016^{*} \\
(0.009)\end{array}$ & $\begin{array}{l}-0.017 * \\
(0.009)\end{array}$ & $\begin{array}{l}-0.008 \\
(0.008)\end{array}$ \\
\hline $\begin{array}{l}\text { Parent's perception of } \\
\text { attainement }\end{array}$ & $\begin{array}{c}0.350 * * * \\
(0.096)\end{array}$ & $\begin{array}{c}0.346 * * * \\
(0.096)\end{array}$ & $\begin{array}{c}0.245^{* *} \\
(0.113)\end{array}$ & $\begin{array}{l}0.017 \\
(0.108)\end{array}$ & $\begin{array}{l}0.028 \\
(0.109)\end{array}$ & $\begin{array}{l}0.115 \\
(0.077)\end{array}$ \\
\hline Girl & $\begin{array}{l}-0.125 \\
(0.116)\end{array}$ & $\begin{array}{l}-0.122 \\
(0.117)\end{array}$ & $\begin{array}{c}-0.275^{* * *} \\
(0.089)\end{array}$ & $\begin{array}{l}-0.204 \\
(0.126)\end{array}$ & $\begin{array}{l}-0.199 \\
(0.127)\end{array}$ & $\begin{array}{l}-0.024 \\
(0.115)\end{array}$ \\
\hline $\begin{array}{l}\text { Years of edu of the } \\
\text { most educated parent }\end{array}$ & $\begin{array}{c}-0.061 * * * \\
(0.023)\end{array}$ & $\begin{array}{c}-0.053 * * \\
(0.024)\end{array}$ & $\begin{array}{l}0.085^{*} \\
(0.047)\end{array}$ & $\begin{array}{l}-0.021 \\
(0.026)\end{array}$ & $\begin{array}{l}-0.011 \\
(0.026)\end{array}$ & $\begin{array}{c}0.104 * * * \\
(0.031)\end{array}$ \\
\hline Rural & $\begin{array}{c}-0.333 * * \\
(0.161)\end{array}$ & $\begin{array}{c}-0.328 * * \\
(0.162)\end{array}$ & $\begin{array}{c}0.162 \\
(0.225)\end{array}$ & $\begin{array}{c}-0.461 * * \\
(0.191)\end{array}$ & $\begin{array}{c}-0.452 * * \\
(0.190)\end{array}$ & $\begin{array}{l}-0.003 \\
(0.206)\end{array}$ \\
\hline $\begin{array}{l}\text { Household head } \\
\text { is a female }\end{array}$ & $\begin{array}{c}0.084 \\
(0.151)\end{array}$ & $\begin{array}{c}0.091 \\
(0.151)\end{array}$ & $\begin{array}{c}0.049 \\
(0.116)\end{array}$ & $\begin{array}{l}0.132 \\
(0.159)\end{array}$ & $\begin{array}{l}0.134 \\
(0.161)\end{array}$ & $\begin{array}{l}-0.046 \\
(0.131)\end{array}$ \\
\hline Wealth index & $\begin{array}{c}-1.298 * * * \\
(0.344)\end{array}$ & $\begin{array}{c}-1.374 * * * \\
(0.342)\end{array}$ & $\begin{array}{l}-0.176 \\
(0.574)\end{array}$ & $\begin{array}{c}-0.791 * * \\
(0.362)\end{array}$ & $\begin{array}{c}-0.914 * * \\
(0.367)\end{array}$ & $\begin{array}{l}-0.261 \\
(0.365)\end{array}$ \\
\hline Malnourished & $\begin{array}{c}0.071 \\
(0.138)\end{array}$ & $\begin{array}{c}0.057 \\
(0.139)\end{array}$ & $\begin{array}{l}-0.074 \\
(0.113)\end{array}$ & $\begin{array}{l}0.132 \\
(0.148)\end{array}$ & $\begin{array}{l}0.122 \\
(0.150)\end{array}$ & $\begin{array}{l}-0.012 \\
(0.108)\end{array}$ \\
\hline Score in maths at 12 & & & & $\begin{array}{l}-0.001 \\
(0.001)\end{array}$ & $\begin{array}{l}-0.001 \\
(0.001)\end{array}$ & $\begin{array}{l}-0.001 \\
(0.001)\end{array}$ \\
\hline Constant & $0.727 * *$ & $0.821^{* *}$ & $-1.134 *$ & 0.429 & 0.377 & $-1.596^{* * *}$ \\
\hline $\begin{array}{l}\text { Second stage equation } \\
\text { Shape of low status } \\
\text { occupation in the } \\
\text { district }\end{array}$ & $(0.350)$ & $(0.357)$ & $(0.644)$ & $(0.474)$ & $(0.470)$ & $(0.521)$ \\
\hline Constant & & & $\begin{array}{c}(0.356) \\
3.417 * * *\end{array}$ & & & $\begin{array}{c}(0.296) \\
3.559 * * *\end{array}$ \\
\hline athrho & & & $\begin{array}{l}(0.482) \\
-1.303^{*}\end{array}$ & & & $\begin{array}{c}(0.422) \\
-1.417 * *\end{array}$ \\
\hline $\ln ($ sigma $)$ & & & $\begin{array}{c}(0.679) \\
0.544 * * * \\
(0.088)\end{array}$ & & & $\begin{array}{c}(0.657) \\
0.457 * * * \\
(0.092)\end{array}$ \\
\hline Observations & 586 & 586 & 586 & 586 & 586 & 586 \\
\hline log likelihood & -319.920 & -315.055 & -1468.454 & -254.914 & -252.065 & -1352.304 \\
\hline
\end{tabular}




\section{Aspiration failure: A poverty trap for indigenous children in Peru?}

This paper aims to contribute to understand the mechanisms underlying the complex exclusion process of indigenous people in Peru, by analysing the role played by aspirations in the investment in education of indigenous children. Aspirations of indigenous children are quite similar to those of non-indigenous children when comparing children with the same socio-economic status. However, indigenous children differ tremendously according to their aspiration gap, that measure the distance between the socio-economic status they aspire to reach and their current one. The distance they have to cover to fill this gap is nearly two times higher than non-indigenous children. But the difference is driven by the highest economic constraints or more limited access to information of indigenous children. This result calls for the rejection of the hypothesis that indigenous children have internalized racial schemas that incorporate beliefs about occupation or about their opportunities, and which would lead to a lack of aspiration for indigenous children.

In addition, this paper shows that large aspiration gap impede indigenous children to adopt forward-looking behaviours, such as investment in education. This paper adopts an original strategy to identify the causal effect of aspiration gap on educational outcomes. It relies on an instrumental variable calculated using the Population Census. Our estimates suggest that the aspiration gap for indigenous children is too large, in so far as it has a positive effect on the probability to repeat a grade. The disincentive effect of large aspiration gap on the effort provided at school becomes more important while the indigenous children grow up, as they may be more aware of the distance between their aspiration and their current status. The results lead us to conclude that aspiration failure is a channel of inequality persistence between indigenous and non-indigenous people. Indeed, we show that indigenous children face a large aspiration gap that affects their decision-making process and leads to underinvestment in education.

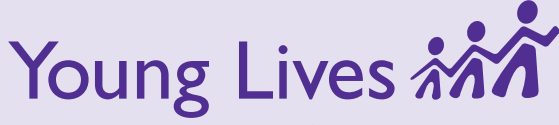 \\ An International Study of Childhood Poverty}

About Young Lives

Young Lives is an international study of childhood poverty, involving 12,000 children in 4 countries over 15 years. It is led by a team in the Department of International Development at the University of Oxford in association with research and policy partners in the 4 study countries: Ethiopia, India, Peru and Vietnam.

Through researching different aspects of children's lives, we seek to improve policies and programmes for children.

\section{Young Lives Partners}

Young Lives is coordinated by a small team based at the University of Oxford, led by

Professor Jo Boyden.

- Ethiopian Development Research Institute, Ethiopia

- Pankhurst Development Research and Consulting plc

- Save the Children (Ethiopia programme)

- Centre for Economic and Social Sciences, Andhra Pradesh, India

- Save the Children India

- Sri Padmavathi Mahila Visvavidyalayam (Women's University), Andhra Pradesh, India

- Grupo de Análisis para el Desarollo (GRADE), Peru

- Instituto de Investigación Nutricional, Peru

- Centre for Analysis and Forecasting. Vietnamese Academy of Social Sciences, Vietnam

- General Statistics Office, Vietnam

- University of Oxford, UK

Contact:

Young Lives

Oxford Department of

International Development, University of Oxford, 3 Mansfield Road, Oxford OX1 3TB, UK Tel: +44 (0)1865 281751

Email: younglives@younglives.org.uk Website: www.younglives.org.uk 